\author{
Military Technical College \\ Kobry El-Kobbah, \\ Cairo, Egypt
}

\section{$9^{\text {th }}$ International Conference on Civil and Architecture Engineering ICCAE-9-2012}

\title{
Effect of Backfill Soil Type and Panel Thickness on Concrete Penetration Resistance
}

\author{
Mohamed. M. Abdel-Kader* and Ahmed A. Fouda**
}

\begin{abstract}
:
Buried civilian shelters that designed against missile effect, require existence of concrete layer on the ground level at a certain distance above the buried shelter. This layer should be strong and thick enough to resist missi le penetration.

In this paper, the effect of backfill soil type on concrete penetration resistance was studied. Damage level due to different impact velocities was also evaluated according to crater dimensions at front and back face of concrete targets. The study showed that using sand as a backfill improved penetration resistance more than using gravel. The study also prevailed the importance of front face reinforcement with increasing target thickness. It was also found that damage level in perforated targets increased with increasing target thickness.
\end{abstract}

Keywords:

Concrete; Penetration; Perforation; Impact; Missile.

\section{Introduction}

Hard missile impact results in both local damage and overall dynamic response of the concrete target. Local damage consists of spalling of concrete from the front impacted face, and scabbing of concrete from the back face of the target together with missile penetration into the target. If damage is sufficient (plenty damage occurs), the missile may perforate or pass through the target. As shown in Fig. 1, compression wave is created through the concrete target due to missile impact. This compression wave reflects when reaches the target back face as a tension wave. Scabbing phenomenon begins at the back face if the reflected tension wave exceeds the concrete tension strength. Boundary conditions of the target (such as backfill soil at the target back face, and the target thickness ) will affect penetration resistance and damage level of the target. These conditions will be studied in the current paper.

* Lecturer, Obour High Institute for Eng. and Tech., Cairo, Egypt. kadermoh@hotmail.com

** Engineering consultant office, Egyptian armed forces, Egypt. Fodaeng@ hotmail.com 

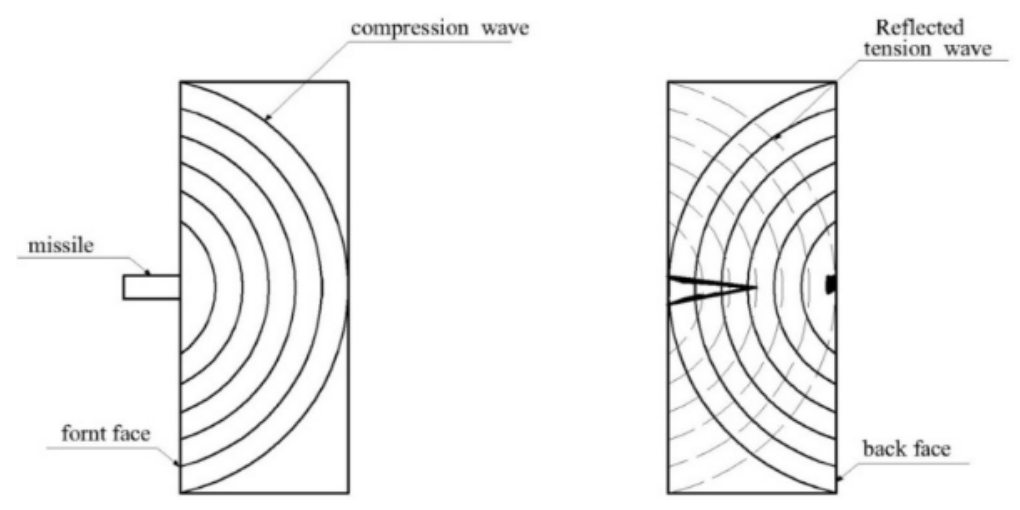

\section{Experiments}

Fig. 1. Impact wave propagation through impacted target

\subsection{Experimental setup}

The tests were conducted in the laboratory se tup described in Fig. 2. The impact load was generated by a gun that accelerate a blunt-nose, hard projectile. The projectile dimensions and mechanical properties are shown in Fig. 3 and Table 1. The projectile impact velocity was measured with electro optical velocity measurement device. The test specimens were mounted on stationary stiff steel frame at distance of 50 meters in front of the gun.

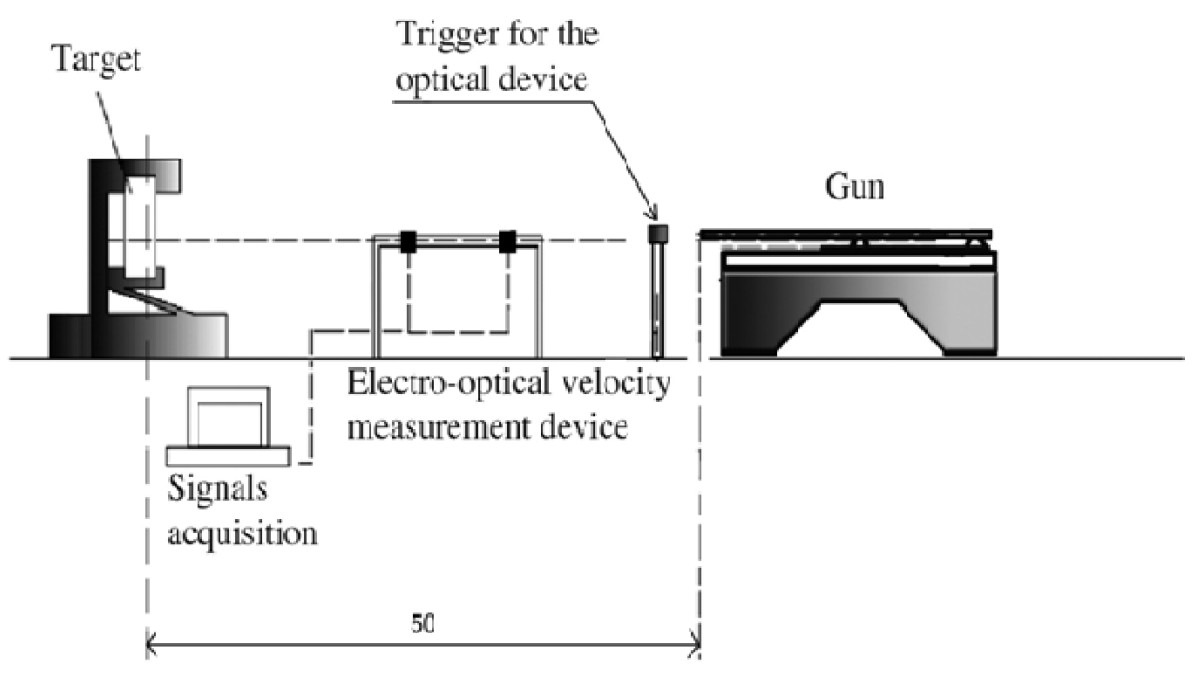

Fig. 2. Scheme of the experimental set up

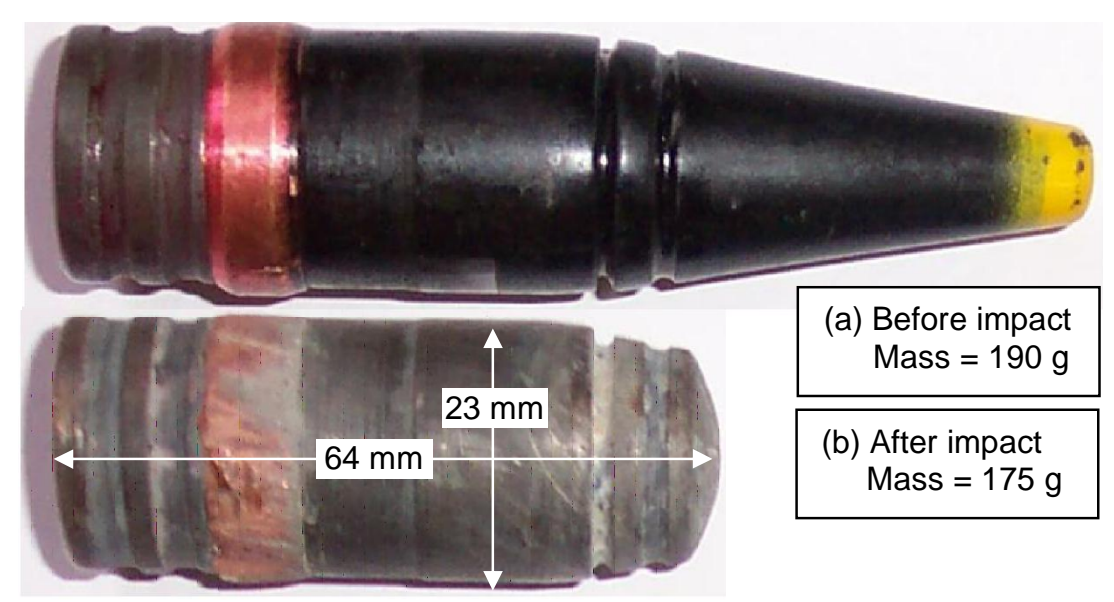


Fig. 3. Dimensions of the projectile

Table 1. Mechanical properties of the projectile

\begin{tabular}{c|c|c|c|c}
\hline \hline $\begin{array}{c}\text { Weight } \\
{[\mathrm{g}]}\end{array}$ & $\begin{array}{c}\text { Brinell hardness } \\
\text { Number }[\mathrm{HB}]\end{array}$ & $\begin{array}{c}\text { Yield strength } \\
{[\mathrm{MPa}]}\end{array}$ & $\begin{array}{c}\text { Ultimate strength } \\
{[\mathrm{MPa}]}\end{array}$ & $\begin{array}{c}\text { Strain at fracture } \\
{[\%]}\end{array}$ \\
\hline 175 & 475 & 1726 & 1900 & 7 \\
\hline \hline
\end{tabular}

\subsection{Test specimens}

Test specimens were plain concrete panels. To avoid the effect of edge condition on penetration results, the minimum dimension of concrete panels should be greater than 20 times the projectile diameter [1]. Therefore, panel dimensions of 50x50 cm were used with different thicknesses. Mix proportion and mechanical prope rties of concrete are shown in Tables 2 and 3, consequently.

Table 2. Proportion of concrete mix

\begin{tabular}{c|c|c|c|c}
\hline \hline $\begin{array}{c}\text { Cement } \\
(\mathrm{OPC}) \\
{\left[\mathrm{kg} / \mathrm{m}^{3}\right]}\end{array}$ & $\begin{array}{c}\text { Coarse aggregate } \\
(\text { Dolomite }) \\
{\left[\mathrm{kg} / \mathrm{m}^{3}\right]}\end{array}$ & $\begin{array}{c}\text { Fine aggregate } \\
(\text { Sand }) \\
{\left[\mathrm{kg} / \mathrm{m}^{3}\right]}\end{array}$ & Water & $\begin{array}{c}\text { Water /Cement } \\
\text { ratio }\end{array}$ \\
\hline 350 & 1100 & 760 & 200 & 0.57 \\
\hline \hline
\end{tabular}

Table 3. Mechanical properties of concrete

\begin{tabular}{c|c|c|c|c}
\hline \hline $\begin{array}{c}\text { Density } \\
{\left[\mathrm{kg} / \mathrm{m}^{3}\right]}\end{array}$ & $\begin{array}{c}\text { Compressive strength } \\
{\left[\mathrm{kg} / \mathrm{cm}^{2}\right]}\end{array}$ & $\begin{array}{c}\text { Flexural strength } \\
{\left[\mathrm{kg} / \mathrm{cm}^{2}\right]}\end{array}$ & $\begin{array}{c}\text { Tensile strength } \\
{\left[\mathrm{kg} / \mathrm{cm}^{2}\right]}\end{array}$ & $\begin{array}{c}\text { Slump } \\
{[\mathrm{mm}]}\end{array}$ \\
\hline 2400 & 260 & 46 & 25 & 85 \\
\hline \hline
\end{tabular}

\subsection{Test plane}

\subsubsection{Effect of backfill soil on penetration resistance}

To study the effect of backfill soil on penetration resistance, 9 panels of $10 \mathrm{~cm}$ thickness were used with $30 \mathrm{~cm}$ backfill of soil at panel back face. Two types of soil [sand (from $0.15 \mathrm{~mm}$ to $5 \mathrm{~mm}$ ) and gravel (from $5 \mathrm{~mm}$ to $40 \mathrm{~mm}$ )] were tested as a backfill. The concrete targets were tested under incremental impact velocity equal to and higher than the perforation velocity for $10 \mathrm{~cm}$ panel without backfill. Table 4 and Fig. 4 show the test results of this stage. 


\subsubsection{Effect of target thickness on damage level}

Number of 24 concrete panels with different thicknes ses were tested. The panels thicknesses were $10,15,20,25,35,40$ and $50 \mathrm{~cm}$. Three to four specimens were tested for each panel thickness under different incremental impact velocity until full perforation of the panel occurred. The perforation velocity was determined eit her according to direct result (when projectile was found near the target) or by proportion between the pre-perforation impact velocity and the velocity that caused perforation. The panels response under impact lo ad was indicated through the damage that happened at both panel faces. The front and back face crater area and depth were measured for each panel thickness under different impact load. The crater area was measured by taking close photo to the crater, then transfer to AutoCAD program, scale the drawing and measure crater area. Table 5 and Fig. 5 show the final test results at perforation.

Table 4. Effect of backfill type on penetration resistance for $10 \mathrm{~cm}$ panels

\begin{tabular}{|c|c|c|c|c|c|c|}
\hline \multirow{2}{*}{ Backfill type } & \multirow{2}{*}{$\begin{array}{l}\text { Impact } \\
\text { velocity } \\
(\mathrm{m} / \mathrm{s})\end{array}$} & \multicolumn{2}{|c|}{ Front face crater } & \multicolumn{2}{|c|}{ Back face crater } & \multirow{2}{*}{ Notes } \\
\hline & & $\begin{array}{l}\text { Area } \\
\left(\mathrm{cm}^{2}\right)\end{array}$ & $\begin{array}{l}\text { Depth } \\
(\mathrm{cm})\end{array}$ & $\begin{array}{l}\text { Area } \\
\left(\mathrm{cm}^{2}\right)\end{array}$ & $\begin{array}{l}\text { Depth } \\
(\mathrm{cm})\end{array}$ & \\
\hline No backfill & 275 & 144 & 3.5 & 563 & 6.5 & $\begin{array}{l}\text { - Full perforation } \\
\text { - Projectile found } \\
\text { near the panel. }\end{array}$ \\
\hline \multirow{3}{*}{$\begin{array}{l}\text { Sand backfill } \\
30 \mathrm{~cm} \text { thickness }\end{array}$} & 283 & 90 & 4.0 & - & - & $\begin{array}{l}\text { - No perforation } \\
\text { - Projectile rebound. }\end{array}$ \\
\hline & 288 & 125 & 4.5 & - & - & $\begin{array}{l}\text { - No perforation. } \\
\text { - Projectile rebound. }\end{array}$ \\
\hline & 335 & 125 & 5.0 & - & - & $\begin{array}{l}\text { - Projectile was } \\
\text { captured inside the } \\
\text { panel without back } \\
\text { face crater. }\end{array}$ \\
\hline $\begin{array}{l}\text { Gravel backfill } \\
30 \mathrm{~cm} \text { thickness }\end{array}$ & 324 & 135 & 4.5 & 185 & 5.5 & $\begin{array}{l}\text { - Full perforation } \\
\text { with formation of } \\
\text { back face crater. }\end{array}$ \\
\hline
\end{tabular}

Table 5. Final perforation test results for panels of different thicknesses

\begin{tabular}{l|l|l|l}
\hline \hline Sample thickness & Perforation velocity & Front face crater & Back face crater \\
\hline \hline
\end{tabular}




\begin{tabular}{c|c|c|c}
\hline \hline$(\mathrm{cm})$ & $(\mathrm{m} / \mathrm{s})$ & area $\left(\mathrm{cm}^{2}\right)$ & area $\left(\mathrm{cm}^{2}\right)$ \\
\hline 10 & 275 & 144 & 563 \\
\hline 15 & 400 & 171 & 222 \\
\hline 20 & 480 & 377 & 311 \\
\hline 25 & 570 & 800 & 1150 \\
\hline 40 & 800 & 960 & 675 \\
\hline 50 & 950 & 1256 & 706 \\
\hline \hline
\end{tabular}

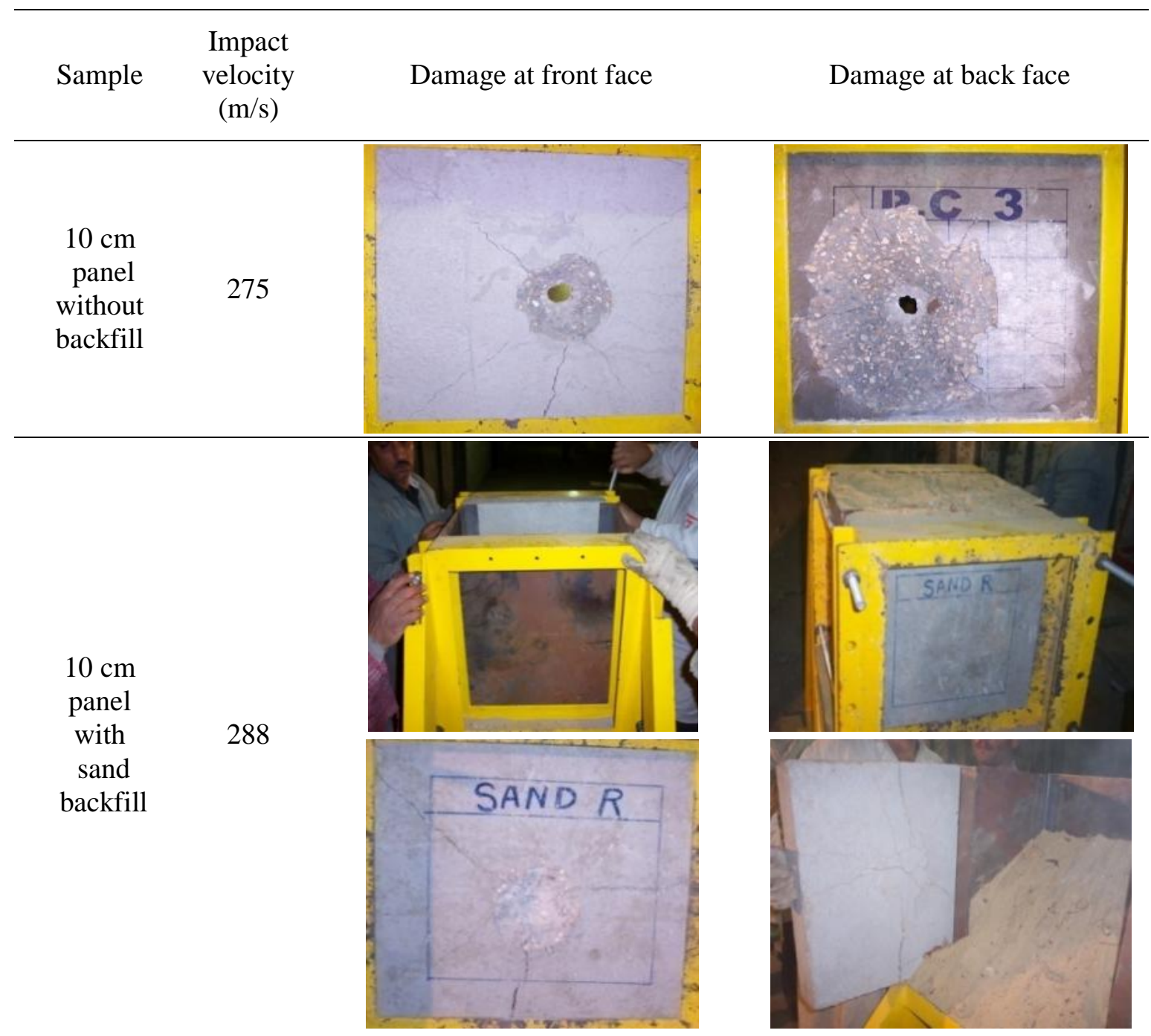




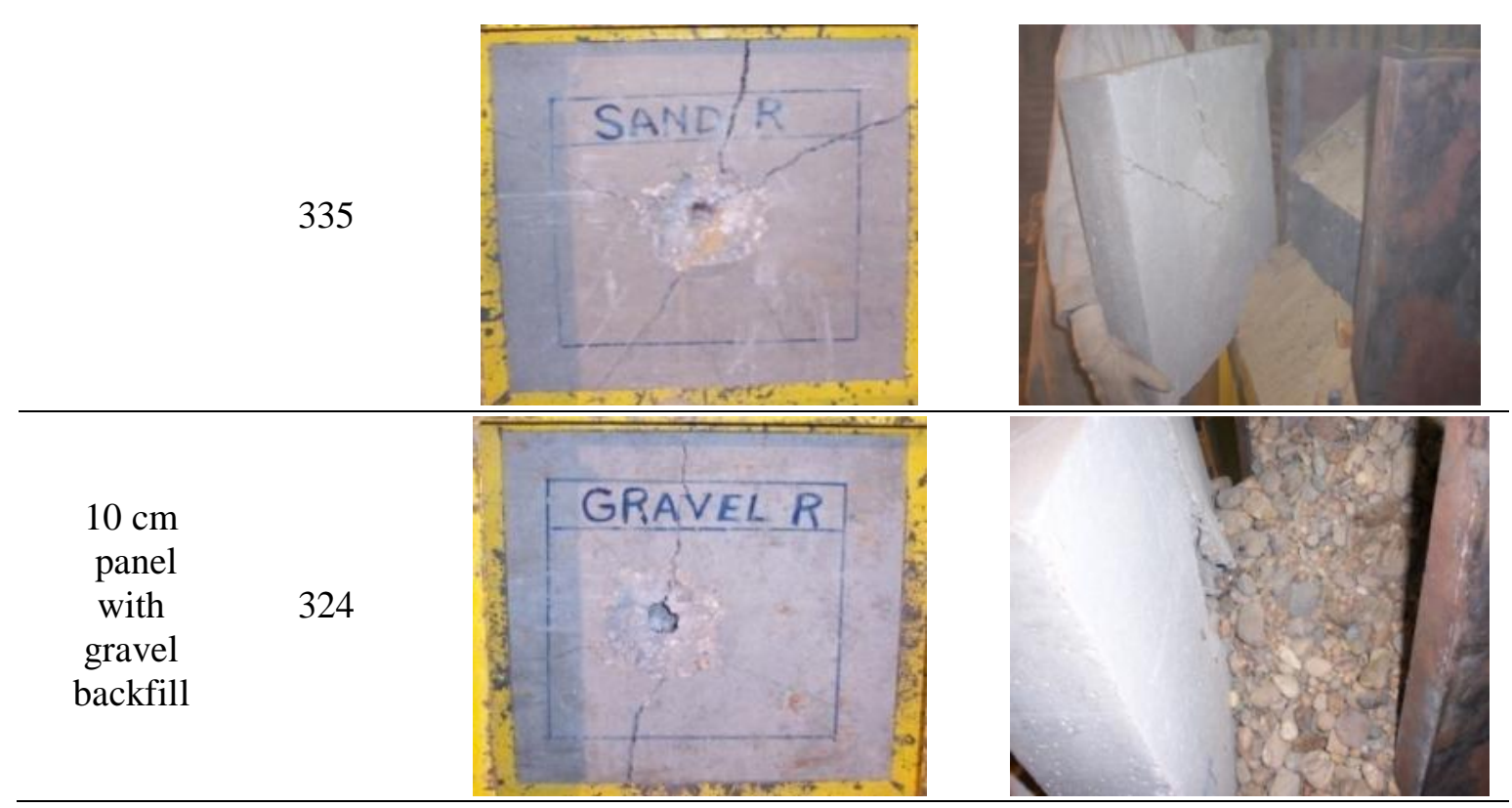

Fig. 4. Effect of backfill soil type on penetration resistance .

\begin{tabular}{|c|c|c|c|}
\hline $\begin{array}{c}\text { Sample } \\
\text { thickness } \\
(\mathrm{cm})\end{array}$ & $\begin{array}{l}\text { Perforation } \\
\text { velocity } \\
(\mathrm{m} / \mathrm{s})\end{array}$ & Damage at front face & Damage at back face \\
\hline 15 & 400 & & \\
\hline 20 & 480 & & \\
\hline 25 & 570 & & \\
\hline
\end{tabular}




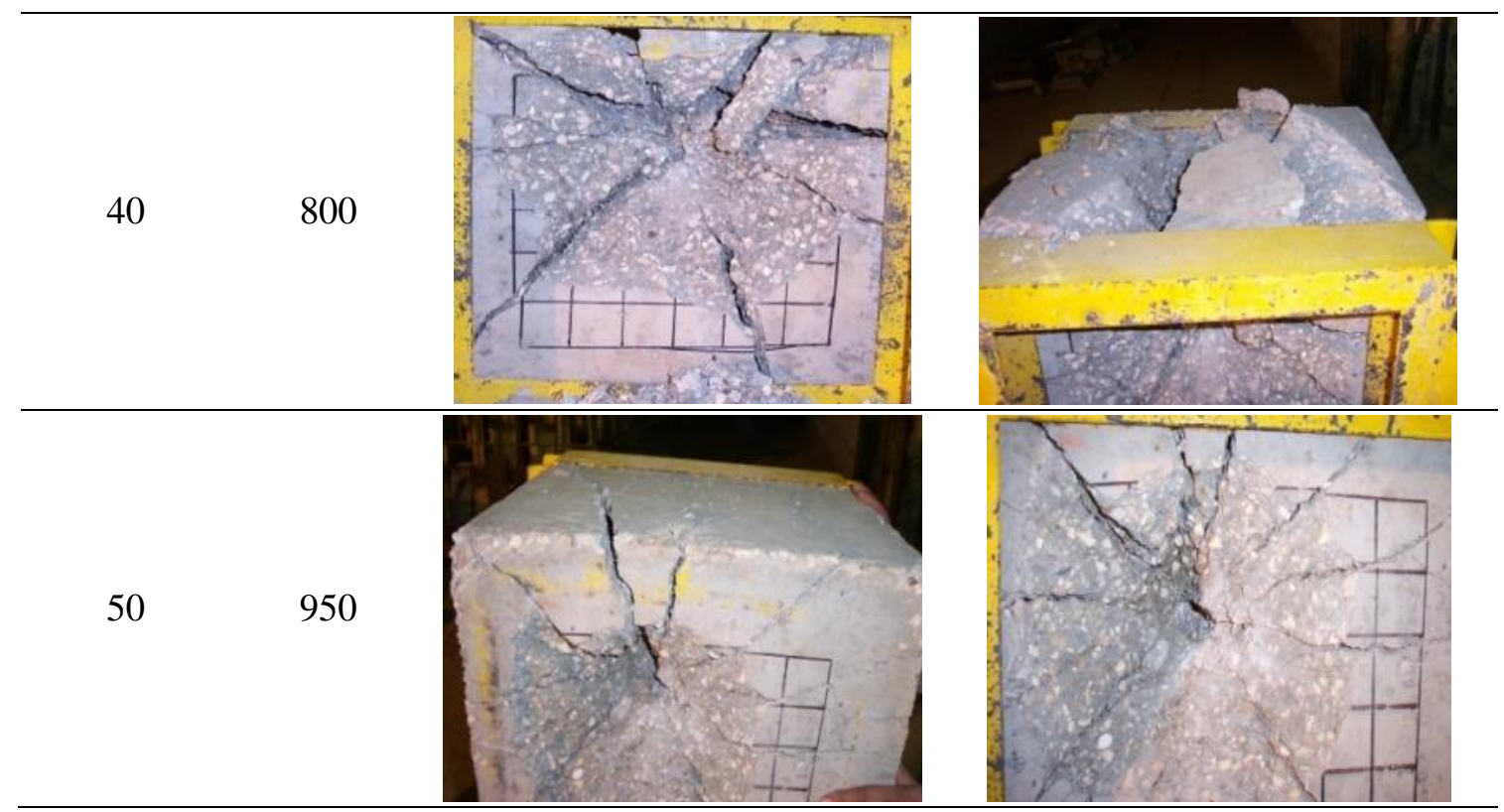

Fig. 5. Final perforation results for panels of different thicknesses.

\section{Results and Discussion}

\subsection{Effect of backfill soil on penetration resistance}

From Table 4 and Fig. 4, the missile velocity that caused full perforation of the $10 \mathrm{~cm}$ concrete panel (without sand backfill) was $275 \mathrm{~m} / \mathrm{s}$. Using sand at the panel back face increased the target capacity to absorb more energy, as impacting velocity increased up to $335 \mathrm{~m} / \mathrm{s}$ without occurrence of perforation. At this velocity, a panel back face upheaval happened at the place of crater area for the same panel without backfill. Around the upheaval area, the cracks were found to be wider and more distributed than the case of the panel without backfill. This behavior could refer to that sand backfill retain the concrete back face material at its place, which produced more penetration resistance. On the other hand, sand backfill work as an elastic support which gave more elastic response to the concrete target. Elastic response distributed the localized effect of impact over wider area, and consequ ently increased the energy absorbing capacity of the target.

In addition to the benefit of retaining scabbing material at target back face and working as an elastic support, sand backfill worked to absorb part of the impacted compression wave as a transmitted compression wave through sand. This leads to reduce the reflected tension wave that caused scabbing phenomenon. According to Smith [2], when stress wave strikes an interface between dissimilar material; the intensity of the transmitted shock $\left(\sigma_{b}\right)$ "from material 1 to material 2 " and the reflected shock $\left(o_{0}\right)$ " through material 2 " can be expressed in terms of the incident shock $\left(\sigma_{a}\right)$ as follows:

$$
\begin{aligned}
& \sigma_{h}=2\left(\frac{\rho_{2} c_{2}}{\rho_{1} c_{1}+\rho_{2} c_{2}}\right) \sigma_{n} \\
& \sigma_{c}=\left(\frac{\rho_{2} c_{2}-\rho_{1} c_{1}}{\rho_{2} c_{2}+\rho_{1} c_{1}}\right) \sigma_{a}
\end{aligned}
$$


Where $\left(\rho_{1}\right)$ and $\left(\rho_{2}\right)$ are the density of materials 1 and 2 , and $\left(c_{1}\right)$ and $\left(c_{2}\right)$ are the propagation velocities of the shock wave in the two materials. According to the previous equations, the transmitted shock from concrete target to sand backfill $\left(\sigma_{b}\right)$ and the reflected shock through concrete panel $\left(\sigma_{c}\right)$ are:

$$
\begin{aligned}
& \sigma_{b}=2\left(\frac{1600 * 180}{2400 * 3000+1600 * 180}\right) \sigma_{a}=0.00 \sigma_{a} \\
& \sigma_{c}=\left(\frac{2400 * 3000-1600 * 180}{2400 * 3000+1600 * 180}\right) \sigma_{a}=0.92 \sigma_{a}
\end{aligned}
$$

where sand density is $1600 \mathrm{~kg} / \mathrm{m}^{3}$ and its shock wave seismic velocity is $180 \mathrm{~m} / \mathrm{s}$, and concrete density is $2400 \mathrm{~kg} / \mathrm{m}^{3}$ and its shock wave seismic velocity is $3000 \mathrm{~m} / \mathrm{s}$ [2]. As it is clear from the previous equations, attenuation to the impacting compression shock wave of about $8 \%$ is obtained during reflection process throu gh sand backfill.

Regarding the panels with gravel as a backfill, it was found that the panels response was better than that without backfill, as smaller front and back face crater are obtained (Table 4). On the other hand, sand backfill was found superi or to gravel backfill; as full perforation to the concrete panel with gravel backfill happened at lower velocity than that required for panels with sand backfill. The damage level "that represented by the front face crater area" was also reduced for panels with sand backfill.

\subsection{Effect of target thickness on damage level}

Damage level at perforation was studied through front and back face crater area for different panel thicknesses. Where perforation is the maximum thickness of a target which a projectile with a given impact velocity will completely penetrate and have a theoretical exit velocity equal zero. Table 6 and Fig. 6 show that when target thickness increases, the ratio between the back face to front face crater area decreases. This implied that rein forcing the panel front face becomes more important as target thickness increases. Decreasing back face damage with increasing panel perforation thickness could refer to the weakness that happened to the impact compression wave through thick targets, and the consequent weakness to the reflected tension wave that causes concrete scabbing.

It is also noted from Fig. 5 that the destruction happened in the concrete panels increased with increasing the target thickness. This could refer to the value of the affe cting force and the duration of impact. According to Kennedy [3], the affecting impact force can reasonably assumed constant throughout the entire duration of impact, and the duration of impact $(T)$ and the average constant impact force $(F)$ "which is the affected impact energy distributed through unit depth" were given by:

$$
\begin{aligned}
& T=2 e / V \\
& F-W V / g T
\end{aligned}
$$

Where $(W)$ is the projectile weight, $(V)$ is the projectile striking velocity, and $(g)$ is the gravity acceleration. As shown in Table 6, the affecting impact force $(F)$ and duration time of impact $(T)$ increased with increasing the panel perforation thickness. This leads to a stronger overall 
response from the panel to resist the affecting impact and consequently a higher damage level was obtained.

Table 6. Damage level, impact force, and impact duration with respect to perforation thickness.

\begin{tabular}{c|c|c|c|c|c|c}
\hline \hline $\begin{array}{c}\text { Panel perforation thickness } \\
(\mathrm{cm})\end{array}$ & 10 & 15 & 20 & 25 & 40 & 60 \\
\hline $\begin{array}{c}\text { Back face to front face crater area } \\
(\text { Back/front) }\end{array}$ & 3.9 & 1.3 & 0.83 & 0.4 & 0.7 & 0.56 \\
\hline $\begin{array}{c}\text { Affecting impact force } \\
\left(\mathrm{N} \times 10^{3}\right)\end{array}$ & 66 & 93 & 100 & 115 & 140 & 168 \\
\hline \hline $\begin{array}{c}\text { Duration of impact } \\
(\mathrm{ms})\end{array}$ & 0.727 & 0.750 & 0.833 & 0.867 & 1.0 & 1.021 \\
\hline \hline
\end{tabular}

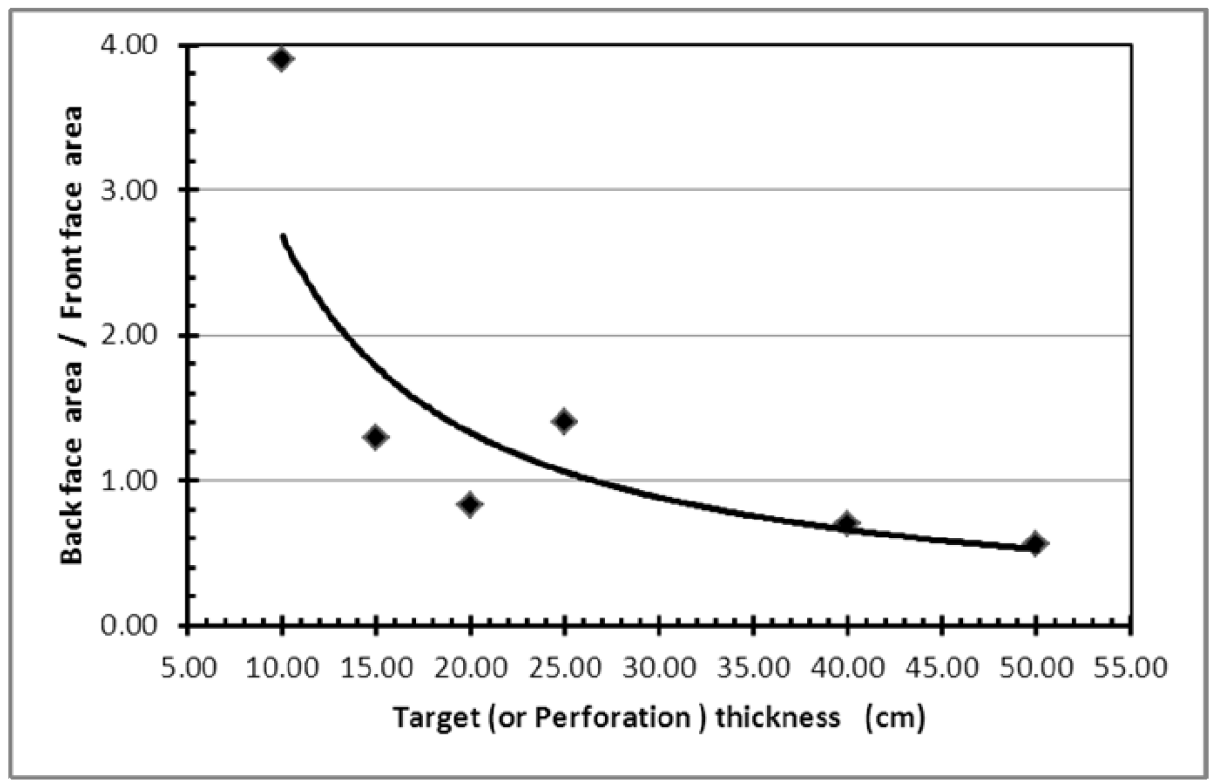

Fig. 6. Damage level for panels of different thickness es 


\section{Conclusions}

Regarding the behavior of concrete panels subjected to impact loads of hard projectile, the following conclusions were obtained by this study:

a) Using backfill at target back face increased panel perforation resistance.

b) Sand was found to be better than gravel as a backfill behind concrete panel.

c) Reinforcing panel front face gets more important as the perforation thicknesses increase.

d) Damage level increased with increasing the target thickness.

\section{References}

[1] Dancygier A.D, "Rear Face Damage of Normal and High-Strength Concrete Elements Caused by Hard Projectile Impact", ACI Structural Journal, Vol. 95. No. 3, pp. 291304, May-June (1998).

[2] Smith P.D, Blast and Ballistic Loading of Structure, Butterworth-Heinemann Ltd, Great Britain, Oxford OX2 8DP, (1994).

[3] KENNEDY R.P, "A Review of Procedures for the Analysis and Design of Concrete Structures to Resist Missile Impact Effects”, Nuclear Engineering and design, Vol.37, pp. 183-203, (1976).

[4] Li Q.M, Reid S.R, and Ahmad A.M, "Critical Impact Energies for Scabbing and Perforation of Concrete Target", Nuclear Engineering and design, Vol. 236, pp. 11401148, (2006).

[5] Mohamed M.E, Eltehawy E.M, "Experimental Analysis of Reinforced Concrete Panels Resistance", Proceedings of the 13th International Conference on Aerospace Sciences and Aviation Technology, ASAT-13," May, pp. 123-134, (2009).

[6] Haldar A., Hatami M., and Miller F.J, "Concrete structure: Penetration Depth Estimation”, Journal of Structural Engineering, Vol. 109, No. 1, January, pp. 245250, (1983).

[7] Kar A.K, "Local Effect of Tornado-Generated Missiles ",ASCE, Vol. 104, No ST5, May, pp. 809-816, (1978). 